\title{
COMPETENCE, COMPLICITY AND COMPLEXITY: \\ HSU-MING TEO ON THE PITFALLS AND NUANCES \\ OF READING AND RESEARCHING POPULAR ROMANCE ${ }^{1}$
}

\author{
Aurora García Fernández² and Paloma Fresno-Calleja ${ }^{3}$
}

Hsu-Ming Teo is a Malaysian-born Australian fiction writer and academic in the field of literature, history, cultural studies, and popular fiction. So far she has published two novels and several short-fiction works, including "Fables of a Fractured City" (2011) and "Road Tales of the Sultan of Pahang" (2012b). Her first novel, Love and Vertigo (2000) won The Australian/Vogel Literary Award and was shortlisted for several other literary prizes including the Dobbie Award for women's fiction. For its part, Behind the Moon (2005), which is a moving coming-of-age story set in Sydney in the 1990s, was shortlisted for the New South Wales Premier's Literary Awards. In both novels she explores the challenges and intricacies of the migrant experience, the drama of living across worlds and traditions and the anxiety provoked by cultural and emotional unbelonging, but she also reminds us of the spoils of the struggle for (self)acceptance and survival, the resilience and humane empathy of her misfit characters. But beyond nationality or identity conflicts and her sharp social and cultural analysis, her novels also reverberate with essential human emotions, such as family love and friendship, that cut

\footnotetext{
${ }^{1}$ Fecha de recepción: 03/12/2020.

Fecha de aceptación: 03/12/2020. This interview was conducted as part of the research project "The Politics, Aesthetics and Marketing of Literary Formulae in Popular Women's Fiction: History, Exoticism and Romance” (FFI2016-75130-P) (AEI/FEDER, UE).

2 Profesora Titular, Departamento de Filología Anglogermánica y Francesa, Universidad de Oviedo, Oviedo, España; $\triangle$ aurora@uniovi.es.

${ }^{3}$ Profesora Titular, Departamento de Filología Española, Moderna y Clásica, Universidad de las Islas Baleares, Palma de Mallorca, España: $₫$ paloma.fresno@uib.es.
} 
across cultural differences and neutralize antagonistic and patronizing Othering alike; for, at the end of the day, we are all polyhedric human beings, we come to conclude. The traps of identity pigeon-holing are not only set for second-generation women in search of family roots or marginalized adolescents in Sydney's western suburbs, but also for reputed writers and academics with an intersectional identity that condones a complex set of "phantom limbs" (2008), as she incisively argues in one of her last articles, "Who Am I without my Trauma? Confessions and Confusions of a part-time Asian Australian" (2020), where she speaks from the perspectives of her three different personae: Dr Teo the academic, Ming the Asian family-member, and Hsu-Ming Teo the fiction writer.

Dr Teo is currently Discipline Chair in the Department of Media, Communications, Creative Arts, Language, and Literature at Macquarie University, in western Sydney. The scope of her vast research output spans from sexual violence in occupied Germany and travel writing, to British imperial culture, and Australian women's literature, among others. Her research in the field of cultural history encompasses monographs such as Cultural History in Australia (2003), which she co-edited with Richard White, a special issue of History Australia on the "History in Popular Culture" (2011), book chapters and articles about $19^{\text {th }}$ and $20^{\text {th }}$ century Australian culture with particular focus on the role and vicissitudes of women. But her special area of interest is the study of romance fiction, which she has often approached from a postcolonial critical lens. She has written extensively on Orientalism and its impact on historical romances, most notably in her book Desert Passions: Orientalism and Romance Novels (2012a) where she traces the lure of the sheik figure for Western women from the days of the Crusades to the present and examines the roots and evolution of women's Orientalist fiction through the analysis of a huge corpus of "literary" works, popular historical romances and films. In her view, women romance writers contributed to feminize the discourse and to reverse the role of 
women as helpless victims of the ruthless and treacherous Arab; in fact, she claims, romance is the only genre that has "determinedly and repeatedly attempted to humanize the Arab or Muslim Other" (216).

Hsu-Ming Teo is a prominent figure in a new wave of academic scholars of the romance genre that in the last decade or so have established Popular Romance Studies as a field of its own. These third-wave scholars no longer deride romance writers or readers but highlight the complexities and diversity of the genre and demand more complicitous and interdisciplinary critical approaches to popular romance. To that end, together with two well-known scholars in the field, Eric Murphy Selinger and Jayashree Kamblé, she has just co-edited the Routledge Research Companion to Popular Romance Fiction (2020), to which she has also contributed with a chapter on "Love and Romance Novels" in which she defines romantic love as "a bundle of ideas, values and feelings, and a historically changeable set of cultural practices" (454). In the following interview, conducted online in November 2020, she kindly "unbundles" some of the intricacies of romantic fiction and romance scholarship for us.

[AURORA GARCÍA FERNÁNDEZ] The first of our questions refers to the ground-breaking anthology of romance scholarship you have recently co-edited with Jayashree Kamblé and Eric Murhpy Selinger, the Routledge Research Companion to Popular Romance Fiction (2020). This is the most recent and comprehensive account of popular romance criticism to date, could you summarize for RAUDEM's readers how this volume reflects the history and recent developments of the genre and its pertinence in the $21^{\text {st }}$ century? 
This volume came about for several reasons. One of them was that Jayashree, Eric and I realized when attending popular romance conferences that young scholars in the field were working with very outdated information, and outdated approaches as well. I guess we were tired of hearing about second-wave feminist critiques of the romance genre in the 21 st century, nearly half a century later. Those scholars kept coming back to questions such as: Is romance good for women? Is it empowering or disempowering? Is it oppressive for them? And all the ways in which the romance genre had failed. But between the mid-1990s and 2013, when we first conceived of the volume, the scholarship on romance had just exploded and had become really interesting. It was not that the second-wave questions about the representation of women, or women's rights, or sexuality were not important anymore, what was really different was that the secondwave scholarship that was produced from the late $70 \mathrm{~s}$-or even the early $70 \mathrm{~s}$ if we count Germaine Greer's The Female Eunuch (1970)- right up to the 1990s was produced by academic scholars who actually didn't like romance and didn't read it. Mostly they didn't have what we call genre competence in the field, so they were making generalizations based on a toolkit that came out of feminist theory, formalist theory or literary theory. This criticism was also very much shaped by the assumption that one romance was interchangeable with another, that all romances were the same, whether they were published in the 1920s, in the 1990s, or in the early 2000s. That approach was useful in terms of setting the feminist agenda, and asking many of the very important questions about romance fiction, but it was very limited as well, because it was done by people who didn't understand the genre or its readers, and they made a lot of assumptions about readers and writers. And having been to so many romance conferences, we knew that romance readers are much more sophisticated than that. Also romance writers are doing much more interesting things now than they were in the $60 \mathrm{~s}, 70 \mathrm{~s}$ and $80 \mathrm{~s}$, and there was 
a sophistication about the genre and the way it had changed, particularly in the 21 st century, that wasn't captured by the earliest scholarship on romance. We wanted to address those issues, so we decided to put together this research companion -it was actually Ashgate at the time, and later Routledge, who approached us and suggested that we should put this research companion together so that there was a single volume which had the latest scholarship. When we prepared the volume, we thought that we could not be completely comprehensive, but what we were going to try and do is to just capture the history of the genre, the history of the scholarship and to address some of the really major subgenres and thematic issues that keep cropping up in the scholarship of the romance genre.

[PALOMA FRESNO-CALLEJA] Taking it from the last part of the previous question and what you were saying about addressing the major sub-genres and the main thematic preoccupations of the genre at present, could you perhaps very briefly summarize or give examples of what those preoccupations are? The consensus among Popular Romance scholars is that we are now in the third wave of romance criticism. What are the main features of this third wave?

The first wave, obviously, was on the feminist question about whether romances were good or bad for women, whether they're empowering or disempowering, or whether they actually conditioned women to accept patriarchy. The second wave was about romance writers writing back and trying to explain what they were doing in terms of their craft. The second wave also encompassed more historical approaches and more institutional histories, so there was, for instance, Jay Dixon's The Romantic Fiction of Mills \& Boon, 1909-1995 (1998). The third wave is pretty much $21^{\text {st }}$-century scholarship, 
although I started in the mid-1990s bringing other disciplinary approaches to the study of romance. But without a doubt, Pamela Regis's A Natural History of the Romance Novel (2003) consolidated and ignited the third wave of romance scholarship: what she did was to treat the romance genre seriously to develop archetypes for romance along the lines of Northrop Frye's archetypes. She codified it so that we could look at the progenitors of the modern romance genre and that was very useful in all kinds of ways. What characterizes the third wave of romance is, first of all, that scholars recognize and understand the huge range and complexity of the genre. We don't make generalizations on the basis of a handful of novels in one particular genre, whether it is Harlequin Mills and Boon category romances or Avon historical romances. We recognize the complexities of publishing and the publishing history, and here we are indebted to the second wave, to what Jay Dixon and Joseph McAleer (1999) did for the history of Mills \& Boon, Paul Grescoe (1997) for Harlequin, as well, and then what John Markert (2016) is doing in the present day.

Third-wave scholars understand that when we read romance we are reading not just the text, we understand that popular fiction goes beyond, that it is a commercial industry and so the paratextual matters, the symbiotic relationship with readers matters. The apparatus around the romance genre such as writers' associations, like the Romance Writers Association of America, the Romance Writers of Australia, the British Romantic Novelists Association, that matters, blogs and social media matter as well. And we understand that the institutional histories of the industry are important because the editors act as gatekeepers to who gets published, what kinds of stories get told. We also understand that digital publishing has revolutionized the romance industry. So the fundamental thing is that academics working in the third wave understand that this is very complex context, we would never make the kinds of assumptions that were made in the 
past, we would never just pick a handful of Mills and Boon novels even from the 21st century and say: Hey, all romances are like that.

The other thing that scholars in the third wave do is bring a range of different disciplinary and interdisciplinary approaches to the study of romance novels. For me, it's the historical, it's the postcolonial. I have worked in colonial discourse and Orientalism, but also in travel and tourism for a long time. Other people come from the ranks of sociology or formalist literary analysis, or they bring a background in gender studies, in religious studies, in Black American studies, and a whole lot of other disciplinary approaches. There's no longer a single feminist approach to studying romance, even a feminist approach nowadays has got to be intersectional, of course. That's another thing that characterizes the third wave of romance scholarship. Another thing that I've alluded to before is that a lot more attention is being paid to the paratextual now: to the covers, to blogs, to author websites, to reviews, there's an inclusion of readers as well, and what readers think about the romance, social media is also a huge part of it as well. Overall, there is a wider attention to the broader context of the romance industry.

And, I guess, where second-wave feminist critics of romance were antagonistic towards the genre, quite often third-wave scholars are what they call "aca-fans", academic fans, and bring a great deal more genre competence to their analyses. For instance, people who write about paranormal and urban fantasy romances, they love reading the genre. It doesn't mean they can't be critical of it, but they also appreciate the nuances, because they have the genre competence. And I'd say that we academics are more humble in terms of our approach to the readers as well, we don't think that the readers are deluded, that they need to be liberated. We don't think that it is the role of the romance novelist or of the academic to set women free and tell them what to read and how they should read it in Janice Radway's terms, to set up a program for revolution (1991: 215). That is not our 
role. In fact, I think now scholars in the third wave actually recognize the knowledge and expertise -quite often superior knowledge and expertise- of para-academic critics, such as Sarah Wendell of Smart Bitches Trashy Books ${ }^{4}$ or Leah and Bea Koch from The Ripped Bodice bookstore. ${ }^{5}$ And so we work in tandem with them, with the Romance Writers of America who have been extremely supportive of romance scholars in terms of providing funding and opening their archives. So there's been a levelling, we don't look down on them, we are not othering them; of course we are "other" because we are approaching romances academically, but we are also part of them, because we are "acafans". ${ }^{6}$ The approach is a lot more respectful and because of that it yields a lot more, particularly in terms of knowledge.

[AGF] An important part of your academic research has been dedicated to the analysis of historical romance, which is also one of the subgenres covered by the Routledge Research Companion to Popular Romance Fiction. In your work you claim that the explanation for the success of the genre is much more complex than sheer escapism, why do you think romance authors and readers still feel so much attracted to history? And to what extent has historical romance changed with time?

\footnotetext{
4 "A hot pink palace of Bitchery," Sarah Wendell and Candy Tan's website "specializes in reviewing romance novels, examining the history and future of the genre, and bemoaning the enormous prevalence of bodacious pectorals adorning male cover models." The blog offers information about books and events, reviews, podcasts, links, free books, etc. In their own tongue-in-cheek admission: "all of the romance, none of the bullshit" (https://smartbitchestrashybooks.com).

${ }^{5}$ The Ripped Bodice is a bookshop located in Culver City, California, and run by sisters Bea and Leah Koch, whose name refers to the so called "bodice rippers", sexually explicit historical romances popular in the 1970s and 1980s whose covers often featured a passionate male figure literally ripping off the woman's clothes (https://www.therippedbodicela.com/).

${ }^{6}$ The term "acafan" or "aca-fan" (academic fan) originated in the 1980s to refer to academics who were also self-declared fans of the popular works they studied.
} 
Definitely it has changed. I think people enjoy reading and writing historical romance because the past is just fun. It's a fantasy world and I think most readers are quite sophisticated, they read romances and they understand that this is the past, but at the same time it's not. I think quite often academics don't do readers sufficient justice in recognizing that readers can hold two contradictory positions in their head at the same time: they read the novels and they think that there are certain things about the past that they're learning about. And yet at the same time, they realize that this is not actually the past, this is a fantasy world, this is what Bakhtin called the chronotope, it's a romantic chronotope that readers enjoy because it's like this fantasy of Regency or Victorian England, or the highlands of medieval Scotland, or the 19th century American Midwest. The chronotope, or the history presented in the chronotope, is what scholars of Disney and its amusement parks have called distory, or disneyfied history. It's like a disneyfied history that acts like an amusement park for romance readers and that's why the past is fun in romance novels because it's this fantasy chronotope with its own amusement park where you go on this emotional roller coaster ride where you learn something about the past, but you have fun doing it as well. And it's all quite sanitized because we are not into the really gritty realism of the past, catgut condoms have made it into historical romances [laughs], but the books don't really talk about sexually transmitted diseases. It is a sanitized, disneyfied past and that is why it is fun. Readers and writers do understand the past and they have fun with it, but, as I said, it is a sophisticated way of reading that academics have not sufficiently appreciated.

But also I think that the 1970s romance novels were very radical. I am thinking about the romance novels of Bertrice Small particularly, which I have written about. She came out of not necessarily historical romance, but women's historical fiction, the mid20th century historical fiction written by people like Jean Plaidy or Margaret Irwin. 
Before academics started studying women's history, women's history novelists were imagining what would the past had been like if women were important, if women's interests and desires mattered, if women were centered in history. I think that the historical romance draws from those roots of women's historical romance more generally. What women novelists did in the 1970s which was really important was to put women's sexuality back into romance, and to put women's sexuality back into the past. At a time when there were all of these discussions about blowback on the sexual revolution, the sexualization of the romance genre came first through women's historical romances, and then into contemporary romances.

There's been a lot of criticism about rape in the 70s, and early 80 s romance novels, but when you look at what they were doing, they were doing two things. First of all, they were not condoning rape, because although the rapist hero often ends up with the heroine, he doesn't do that until he's brought to see the error of his ways, that what he did was degrading and humiliating, and he has to do this whole repentance and grovelling and change his character before he is a hero; so it's not the rapist figure who is acceptable as a hero, it is the reformed figure. And when you look at the broader historical context at a time when divorce laws were still being contested and enacted, and domestic violence was -and still is- quite prevalent, what these writers were doing was working through issues of violence against women. In that sense, the historical romance novel functions as a forum, as a vehicle to think about violence towards women and to say this is not acceptable, what is acceptable is the reform of the romantic partner, because he's got to put the safety and the needs and the desires of women first rather than his own desires, especially when it manifests itself violently.

The other thing that romance writers were doing was to democratize the debate over issues such as rape and vindicate women's resilience. At that time, especially in America, 
feminism felt the impact of Susan Brownmiller's Against Our Will (1975), the influential book where she makes that very famous declaration that all men are potentially rapists and which made anti-rape activism break into this really huge thing. But in the discourse of anti-rape activists, women never ever recover, they are traumatized for ever. By contrast, the historical romance novel comes along and says, what happens to women in the context of rape is absolutely terrible, and it is wrong and it is criminal, but women get over it, because they are stronger than that. So in terms of the rape romances of the $70 \mathrm{~s}$ that was what was happening and the genre served as a public platform for ordinary women to have their say about the salient issues of the day. It is in this sense that I claim that the historical romance novel became a democratizing platform or a democratizing vehicle, because it's avoiding the gatekeepers of formal feminism, of formal and academic history -all these academics who often delegitimize the efforts, and the thoughts and opinions of amateur historians, or ordinary women. The historical romance novel is where women can have that fantasy, play around with the past, make up their own the past which they find acceptable, indulge in the fantasy and still drip feed certain things about how they thought women should and should not be treated, about violence, about sexuality and all of that. Now, if you come from outside of the field, as an academic critic, you're going to not understand what they're doing and that's why we've got so much criticism of them, but if you've got that genre competence, then you're recognizing that actually they are doing something different.

I also think that compared to the 70 s, 80 s historical romances are quite boring, it all becomes very sexualized, it's fabios ${ }^{7}$ everywhere [laughs]. In the $21^{\text {st }}$ century or from the

\footnotetext{
${ }^{7}$ The term derives from the name of Fabio Lanzoni, an Italian-born American-based actor and model who featured in semi-clad attire on the covers of many romance novels during the 1980s and 1990s, and it is used to refer derogatorily to the stereotyped sexy and muscular male figures that heroes in popular romance novels have often been associated with.
} 
90s onwards at least, when Beverly Jenkins starts writing Black American historical romance then suddenly the historical romance has a new lease of life. What Beverly Jenkins does is use the genre as a way of returning to African American women their own history in a way that is entertaining and enjoyable, but also deeply educational. For women who may not have had the chance to go to university, or who went to school when black history was not a subject and who, therefore, might not know very much about their own past what Jenkins and all the other black American historical novelists after her did was to turn the romance genre into a way of celebrating and educating black American women about their own history. They showed them that in the history of abolitionism black people were key, that they were professionals, that black people engaged in all of this work of social uplift, and it's terrific even though a lot of it is anachronistic and there are of course some inaccuracies, but so are there in school history textbooks. I think it is from that time onwards that the historical romance became very interesting, because it became a way of telling lots of different kinds of histories, and that has continued in the 21st century. We look at LGBTQIA+ histories, trans histories, Chinese histories, all kinds of histories are being brought into this genre for people to play around with it. In the $21 \mathrm{st}$ century, because of the internet and social media, the conversations around the historical romance has just exploded so that now they are centrifugal, they spread out towards readers, so that readers have a say about the past as well. These novels then are democratising not just because authors are able to present and imagine the past, but because readers are able to engage with it as well.

[PFC] Diversity was the other thing that we wanted to touch upon. The romance formula has proved tremendously flexible at incorporating new experiences and new target readers, but it has also been a means to assimilate 
readers to a westernized view of love. Could we say that while Eastern economies are conquering global markets, the western romance is conquering local hearts?

I think that the popular culture of romantic love has become Americanised because we all want that happy ending and what Catherine Roach writes about in Happily Ever After (2016): find your one true love and live happily ever after. That is a very American thing and it's very tied up with the pursuit of happiness, which is tied up with the pursuit of romantic love. We see that model imported into Chinese dramas, for example. Huike Wen (2020) has written a monograph that is coming out about Chinese television and these American models of romance. China, as Lynn Pan (2015) shows, did not historically have monogamous or equal romantic love between men and women. So I do think that westernised Americanised models of romantic love have become global and transnational, but at the same time they have become appropriated and incorporated into different cultures. I think that different cultures are finding different ways of appropriating and hybridising these narratives of love. For instance, Kathrina Haji Mohd Daud works on Muslim narratives of love, particularly in the Indonesian soap opera or sinetron. There is, of course, a lot of stuff which is being produced in Bollywood, Filipinos are doing their own thing as well. I guess the answer to the question is both yes and no. Once these discourses become globalised it does not mean that they are invasive, what it means is that they become discourses which can be appropriated by other cultures and hybridised. They are malleable.

[AGF] In the introduction to The Popular Culture of Romantic Love in Australia you explain that love does not figure prominently in Australian literature. Is it to be assumed that this is mostly related to the predominance of the masculinist 


\section{ethos in the Australian national narrative or is it also tainted by a publishing and academic bias to more epic/masculine topics? How does Australia compare to other national traditions in this respect?}

I do think that the lack of romantic love in Australian literature is partly because of the masculinist ethos, but I think it has more to do with when Australian literature began to be produced. Normally, the 1890s are seen as the watershed years for Australian literature, that is when Australian literature began to come into its own with Henry Lawson, Banjo Paterson, or Marcus Clarke. The masculinist ethos certainly applies there because they had that idea about freedom and being manly did not involve being tied down by domesticity. But if I have a look at the later history of Australian literature, I think that love does not feature in it because Australian literature comes into its own in the $20^{\text {th }}$ century. British and American literature come into their own in the late $18^{\text {th }}$ and $19^{\text {th }}$ centuries. The $19^{\text {th }}$ century is a sentimental century, the $19^{\text {th }}$ century believed in happy endings. But gradually, by the 1890s and then the early 1900s, the aesthetics of modernism takes over as the predominant literary aesthetic and it dominates until the present day. Rita Felski talks about this in The Gender of Modernity (1995). The aesthetic of modernism has become dominant because it is not sentimental, it is spare, it is not emotional, it is not gushing and effusive because that is regarded as feminine. This is a certain type of masculine understanding of literature, but it has become dominant. If you think about what is celebrated in literature, it is the modernist masculine aesthetic. Australian literature begins to be produced in the 1890s onwards, it coincides with modernism and with a rejection of romantic love and the happy ending because tragedy is the mode of the modernist aesthetic. I think that's why Australian literary writers have been uncomfortable with romantic love. It's several things: it's the nationalist tradition, it's the masculinist tradition, it's the modernist aesthetic, and it is also this deep suspicion 
about what Americans find so easy to accept, which is to fall in love and find your happy ending. In Australian history it's not like that because we have had a different history of gender relations.

That is one of the reasons why love does not figure prominently in Australian literature, which is not to say that they do not write about love, they just become more sceptical and questioning about what love is, what love is for, what love can do, whether love can actually make you happy, what it means to actually be in love anyway, it's not as simple as the Americans say. There is a resistance, even maybe a bewilderment! [laughs] But there are also really fine explorations of love in literature and popular culture, of course. One literary romance which I think is one of the best Australian romances is Oscar and Lucinda (1988) by Peter Carey. Although it's got a sad ending, I do think that's probably on par with other national romantic novels, there aren't many, but for me that definitely is a good example. There are the popular manifestations of it, in terms of romance novels, melodramas and soap operas, and of course examples like Baz Luhrmann's Australia (2008). But if you ask people about the film, they will say that Australia is a great film because it makes the outback look really good [laughs], and they talk about the bombing of Darwin. But if you ask them whether the film portrays a convincing love story, I cannot think of anyone I know who would say that the film shows a convincing persuasive love story.

[AGF] I think it would be very interesting to see how all that is changing. I am thinking of Anita Heiss's novels, for instance, and the new ways she has been claimed a place for Indigenous heroines in Australian love stories. I think that she is bringing new credibility to the story, to how to present love in Australia. 
Yes, there is more confidence now. This is partly because of chick lit bridging the gap between the romance and literature, and because of the success of the rural romance or "chook lit", with authors like Rachel Jones, and also Anita Heiss's work, which she herself calls "choc lit"". But I think that feminist scholarship has been central in showing that the needs and desires of women are important as well. If this is what women want to read about these authors are providing another avenue apart from the modernist aesthetic. There is more confidence in terms what popular fiction can do now.

[PFC] The Australian national tradition associated women with the urban and domestic lifestyle. Would you say that the proliferation of "chook" fiction seems to be reversing the story? To what extent is this new subgenre contributing to make the bush a less maddening place for ladies? Would you say it is allowing women to inscribe their experience in the land?

Well, if you read Australian Women's romantic fiction from the 1890s and 1890s onwards they show that the bush is a difficult place, but also that women belong there, and women were pioneers, and women were making the bush safer for men. Australian women particularly make love work in the bush because they had this ethos of hard work and they were incredibly capable.

\footnotetext{
8 There is a humorous pun on the use of the Australian informal term for chicken, "chook", instead to "chick" to refer to popular rural romance in Australia.

${ }^{9}$ Again, a pun on the term "chick lit" to humorously inscribe the fact that Anita Heiss and her heroines are Indigenous Australians. Coincidentally, Choc Lit is also an independent UK publisher specialised in “quality women's fiction".
} 
[PFC] Would you say then that these contemporary romances are somehow recovering those same ideas?

Well, I think these ideas have been forgotten and these authors have rediscovered them. But it is not a new thing because from the 1880s that masculinist tradition of the Bush belonging to men has been challenged by some of our most famous early Australian writers: Rosa Praed or Mary Gaunt, for instance. All of these novelists were showing that women do belong in the Bush and they are capable, in fact they are much more capable and they deserve a happy ending because they are not like British women who only know how to live middle-class urban lives. That is one of the myths that Australian women tell about themselves.

[AGF] Apart from your scholarly work, you are a novelist. In several interviews you mention that you are now working on your third novel. How has your academic work on romance and love influenced your work as a novelist?

Well, I wish I hadn't said that because my work at university has not given me the time to work on my third novel. I think romance as a genre has not had much impact on the first couple of novels. But I had been studying love for a very long time and I think that the scholarship on love definitely is there in Love and Vertigo, which is in many ways an anti-romance. One of the things about Love and Vertigo is that it defamiliarizes love. The characters fall in love because they recognize it on the screen when they go to the movies, or they pick it from poetry. That notion of love as something which is indefinable, the fact that everybody thinks that they know what it is but is quite hard to pin down is in Love and Vertigo already. The other academic work that I had done on sexual violence had more of an impact on Love and Vertigo. My work on postcolonialism and 
multiculturalism is reflected in Behind the Moon, my second novel. As for my current creative work, I have recently written a series of flash fiction that I was performing with Shu-Cheen $\mathrm{Yu}$, an opera singer friend of mine. Some of the songs she was singing were Chinese, others were Australian, and I wrote short flash fiction pieces of about 500-700 words responding to the emotion in the song and to the music. There was a love song, "My Dark-Eyed Acushla" by the Australian composer Horace Keats, and I had to write and perform my first love story, "Acushla of the Goldfields", [laughs], which confirmed my opinion that a romance novel is much harder to write than a literary novel, simply because the romance genre has been done to death. If you are writing a romance you would have to write something fresh, something new and original, something revelatory, whereas in a more literary work you do not have the same pressures, with romance you are writing for a readership that is very competent in the genre.

$$
* * *
$$

By way of conclusion, Hsu-Ming Teo shares her excitement for the future of the discipline: "It's a very exciting time to be a romance scholar because you are not just speaking to your academic colleagues but with people in the industry, people who are incredibly knowledgeable of the field." For us it has been a privilege to talk to her and we thank her for a most generous dialogic lecture hoping that this interview will contribute to better genre competence and the expansion of popular romance scholarship in Spain.

\section{Works cited}

Brownmiller, Susan 1975. Against Our Will: Men, Women and Rape. New York: Simon and Schuster.

Carey, Peter 1998. Oscar and Lucinda. St. Lucia, Qld.: Queensland University Press. 
Dixon, Jay 1998. Romantic Fiction of Mills \& Boon, 1909-1995. London: Routledge.

Felski, Rita 1995. The Gender of Modernity. Cambridge, Mass.: Harvard University Press.

Grace V. S. Chin \& Kathrina Mohd Daud, eds. 2017. The Southeast Asian Woman Writes Back: Gender, Identity and Nation in Brunei Darussalam, Malaysia, Singapore, Indonesia and the Philippines. Singapore: Springer.

Greer, Germaine 1970. The Female Eunuch. New York: McGraw-Hill.

Grescoe, Paul 1997. The Merchants of Venus: Inside Harlequin and the Empire of Romance. Vancouver: Raincoast Book Distribution.

Kamblé, Jayashree Eric Murphy Selinger, Hsu-Ming Teo 2020. Routledge Research Companion to Popular Romance Fiction. London: Routledge, Taylor and Francis Group.

Luhrmann, Baz 2008: Australia. $20^{\text {th }}$ Century Fox.

Markert, John 2016. Publishing Romance: The History of an Industry, 1940s to the Present. Jefferson, North Carolina: McFarland Publishers.

McAleer, Joseph 1999. Passion's Fortune: The Story of Mills \& Boon. Oxford: Oxford University Press.

Pan, Lynn 2015. When True Love Came to China. Honk Kong: Honk Kong University Press.

Radway, Janice A. 1991. Reading the Romance: Women, Patriarchy, and Popular Literature, $2^{\text {nd }}$ ed. Chapel Hill and London: University of North Carolina Press.

Regis, Pamela 2003. A Natural History of the Romance Novel. Philadelphia: University of Pennsylvania Press.

Roach Catherine M. 2016. Happily Ever After: The Romance Story in Popular Culture. Bloomington: Indiana University Press.

Teo, Hsu-Ming 2000. Love and Vertigo. St Leonards, NSW: Allen \& Unwin.

Teo, Hsu-Ming 2005. Behind the Moon. St Leonards, NSW: Allen \& Unwin.

Teo, Hsu-Ming 2008. "Phantom Limbs and Cultural Ventriloquism: Communicating Cultural Difference as a Novelist", Journal of Australian Studies 32. 4: 521-529.

Teo, Hsu-Ming 2011. "Fables of a Fractured City", Asia Literary Review http://www.asialiteraryreview.com. [02/12/2020].

Teo, Hsu-Ming 2012a. Desert Passions: Orientalism and Romance Novels. Austen: University of Texas Press.

Teo, Hsu-Ming 2012b. "Road Tales of the Sultan of Pahang”, Journal of the Association $\begin{array}{lllll}\text { for the Study of Australia } & \text { (JASAL) } & \text { 12.2. }\end{array}$ https://openjournals.library.sydney.edu.au/index.php/JASAL/. [02/12/2020]. 
Teo, Hsu-Ming 2017. The Popular Culture of Romantic Love in Australia. Melbourne: Australian Scholarly Publishing.

Teo, Hsu-Ming 2020. "Who Am I without my Trauma? Confessions and Confusions of a part-time Asian Australian", Peril Magazine: Asian-Australian Arts and Culture 41.

Teo, Hsu-Ming 2020. "Love and Romance Novels," Routledge Research Companion to Popular Romance Fiction. Eds. Jayashree Kamblé, Eric Murphy Selinger and HsuMing Teo. London: Routledge, Taylor and Francis Group. 454-484.

Teo, Hsu-Ming \& Richard White 2003. Cultural History in Australia. Sydney: University of New South Wales Press.

Wen, Huike 2020. Romance in Post-Socialist Chinese Television. New York and London: Palgrave Macmillan.

Wendell, Sarah 2009. Beyond Heaving Bosoms: The Smart Bitche' Guide to Romance Novels. New York: Simon and Schuster. 